\title{
Systematics and distribution of the genus Johnsonius Marsh (Hymenoptera, Braconidae, Doryctinae) with description of two new species from Brazil
}

\author{
Juliano F. Nunes ${ }^{1} \&$ Angelica M. Penteado-Dias ${ }^{2}$
}

\begin{abstract}
${ }^{1}$ Programa de Pós-Graduação em Ecologia e Recursos Naturais, Universidade Federal de São Carlos.
${ }^{2}$ Universidade Federal de São Carlos, Departamento de Ecologia e Biologia Evolutiva - Rodovia Washington Luís, km 235, 13565-905

São Carlos-SP, Brasil. fiorelini@gmail.com, angelica@power.ufscar.br
\end{abstract}

\begin{abstract}
Systematics and distribution of the genus Johnsonius Marsh (Hymenoptera, Braconidae, Doryctinae) with description of two new species from Brazil. The genus Johnsonius Marsh includes five species, most of them known from Costa Rica and one known from Venezuela, Peru and Costa Rica. Two of these species and two new species were recently collected in Atlantic rain forest. Description of the new species, illustrations of some morphological characters, a key for identification of all known species and the new geographic records are presented.
\end{abstract}

KEYWORDS. Atlantic rain forest; neotropical; parasitoid.

RESUMO. Sistemática e distribuição do gênero Johnsonius Marsh (Hymenoptera, Braconidae, Doryctinae) com descrição de duas novas espécies do Brazil. O gênero Johnsonius Marsh inclui cinco espécies, a maioria delas conhecidas na Costa Rica e uma conhecida na Venezuela, Peru e Costa Rica; duas destas espécies e duas novas espécies foram recentemente coletadas na Floresta Atlântica ombrófila. Descrição das novas espécies, ilustrações de alguns caracteres morfológicos, uma chave para identificação de todas as espécies conhecidas e os novos registros geográficos são apresentados.

PALAVRAS-CHAVE. Mata Atlântica Ombrófila; neotropical; parasitóide.

Johnsonius Marsh, 1993 belongs to the subfamily Doryctinae, one of the largest and most diverse groups of cyclostome Braconidae (Hymenoptera). The Doryctinae differ from the other cyclostomes by the presence of a row of short spines on the anterior edge of fore tibia, by a flange on the apico-lateral edges of the propleuron and by the apex of the ovipositor with a double node dorsally (Marsh 1993).

This subfamily is distributed worldwide, with about 150 described genera (Marsh 1997), but as more studies are made on the Neotropical fauna, the number of World genera could reach 200 or more (Marsh 2002). Doryctinae show a wide range of biological habits, perhaps one of the most diverse in the family Braconidae. Most species, for which the biology is known, are idiobiont ectoparasitoids of wood-boring beetle larvae and a few, attack stem boring Lepidoptera and sawflies larvae (Marsh 1997). Although many doryctines attack beetle larvae in seeds, a few species are now known to be phytophagous in seeds (Macêdo \& Monteiro 1989; Marsh 1991 ) or to be gall inducers in various tropical plants (Wharton \& Hanson 2005).

The genus Johnsonius was described by Marsh (1993) with three species: J. hansoni Marsh, 1993, J. tricolor Marsh, 1993 known only from Costa Rica and J. xanthus Marsh, 1993 known from Venezuela, Peru and Costa Rica. Later, Marsh (2002) added two more species from Costa Rica: $J$. costaricensis Marsh, 2002 and J. perknus Marsh, 2002. Scatolini \& Penteado-Dias (2003) recorded the genus from Brazil but did not indicate any species names.
The genus Johnsonius can be recognized by the following characters: hind wing vein m-cu curved at tip toward wing apex; propodeum usually with distinct median carina and areola; hind coxa with a distinct basal tubercle and the clypeus which is usually dorsally margined.

This contribution results from the study of Doryctinae fauna collected in Atlantic rain forest in Brazil and provides the description and illustrations of two new species of Johnsonius with new geographic records and includes a key for the identification of all Neotropical species.

\section{MATERIALAND METHODS}

The Doryctinae fauna was surveyed in 18 localities in Brazil as part of (BIOTA/FAPESP Program) which is aimed at studying the biodiversity of the São Paulo State and of the Atlantic rain forest. Sampling methods used in this study include sweeping of vegetation with nets, yellow pan traps and Malaise traps. The material was sampled during six days always in the end of the rainy season, for avoiding the seasonal variation, during 2000 to 2002.

The Doryctinae specimens were mainly identified using the key provided by Wharton et al. (1997), and their genera and species following Marsh (1993, 1997, 2002).

The material was illustred by Scanning Eletronic Microscopy (SEM). The type specimens are deposited in DCBU collection (Departamento de Ecologia e Biologia Evolutiva, Universidade Federal de São Carlos, São Carlos, SP, Brazil) 
and MZUSP (Museu de Zoologia da Universidade de São Paulo, São Paulo, SP, Brazil).

\section{RESULTS}

A total of 44 specimens were collected in 12 of 18 localities studied (Table I). Santa Luzia do Itanhy, Sergipe State and Santa Maria Madalena, Rio de Janeiro State were the localities with more specimens collected, a total of 11 specimens, respectively.

Johnsonius atlanticus n. sp. was the more common and widely distributed with 20 specimens from five localities into four Brazilian States (Tab. I, Fig. 13) from 1258'16"S to $26^{\circ} 13^{\prime} 40^{\prime \prime} \mathrm{S}$.

Six specimens of Johnsonius marshi $\mathbf{n}$. sp. were collected in two localities of Southeast and South of Brazil; J. costaricensis was restricted to Northeast region of Brazil and 15 specimens of $J$. xanthus were collected in four localities of Southeast and Northeast of Brazil.

Sweeping of vegetation was the best method used, collecting 41 specimens; two specimens were caught using yellow pan traps and only one specimen by Malaise trap (Tab. I).

The distribution of Johnsonius, is restrict to New World from about $10^{\circ} \mathrm{N}$ to $26^{\circ} \mathrm{S}$ (Fig. 13).

Key to the Neotropical species of Johnsonius Marsh

1. Fore wing vein $1 \mathrm{CU}$ swollen between veins $1 \mathrm{M}$ and $1 \mathrm{cu}-$ a (see Fig. 275 in Marsh 2002) ..... J. hansoni Marsh
Fore wing vein $1 \mathrm{CU}$ not swollen 2

2(1). Body unicolored orange or yellowish .. J. xanthus Marsh Body often colored with black, brown, yellow and orange

3

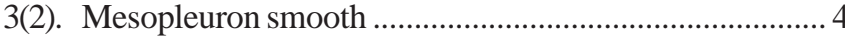
Mesopleuron coriaceous (Fig. 9) ................................... 6

4(3). Sternaulus scrobiculate (see Fig. 231 in Marsh 2002) .. Sternaulus smooth J. perknus Marsh

5(4). Areola on propodeum not distinctly defined, head orange, first metasomal tergum black

J. tricolor Marsh

Areola on propodeum distinctly defined (Fig. 3), head honey yellow with vertex brown, first metasomal tergum yellow J. marshi n.sp

6(3). Notauli meeting before scutellum in longitudinal costate area, metanotum carinate (see Fig. 226 in Marsh 2002), head and mesosoma dark brown

J. costaricensis Marsh

Notauli meeting before scutellum in a large triangular rugose area, metanotum smooth (Fig. 8), head yellow, mesosoma mostly yellow or honey yellow

J. atlanticus $\mathbf{n} . \mathbf{s p}$

Table I. Identified species of Johnsonius from Atlantic rain forest with its sampling sites, geographical position and sampling methods used.

\begin{tabular}{|c|c|c|c|}
\hline Place & Geographical coordinates & Species & Method/Specimens \\
\hline $\begin{array}{l}\text { Horto Dois Irmãos } \\
\text { (Recife, PE) }\end{array}$ & $\begin{array}{l}08^{\circ} 03^{\prime} 14^{\prime \prime} \mathrm{S} \\
34^{\circ} 52^{\prime} 52^{\prime \prime} \mathrm{W}\end{array}$ & J. costaricensis & Sweeping/1 male \\
\hline Reserva Ecológica do Crasto & $11^{\circ} 21^{\prime} 03^{\prime \prime S}$ & J. costaricensis & Sweeping/1 female \\
\hline (Santa Luzia do Itanhy, SE) & $37^{\circ} 26^{\prime} 54^{\prime \prime} \mathrm{W}$ & J. xanthus & Malaise trap / 1 female;Sweeping/ 1 female, 8 males \\
\hline Reserva de Sapiranga & $12^{\circ} 58^{\prime} 16^{\prime \prime S}$ & J.atlanticus n. sp. & Sweeping/1 female \\
\hline (Mata de São João, BA) & $38^{\circ} 30^{\prime} 39^{\prime \prime} \mathrm{W}$ & J. xanthus & Sweeping/1 female, 2 males \\
\hline $\begin{array}{l}\text { Mata da Esperança } \\
\text { (Ilhéus, BA) }\end{array}$ & $\begin{array}{l}15^{\circ} 00^{\prime} 54^{\prime \prime} \mathrm{S} \\
39^{\circ} 00^{\prime} 10^{\prime \prime} \mathrm{W}\end{array}$ & J. costaricensis & Sweeping/1 male \\
\hline $\begin{array}{l}\text { Estação Ecológica Pau Brasil } \\
\text { (Porto Seguro, BA) }\end{array}$ & $\begin{array}{l}16^{\circ} 233^{\prime} 33^{\prime \prime} \mathrm{S} \\
39^{\circ} 11 ' 39^{\prime \prime} \mathrm{W}\end{array}$ & J. xanthus & Sweeping/1 female \\
\hline $\begin{array}{l}\text { Reserva Biológica do Sooretama } \\
\text { (Linhares, ES) }\end{array}$ & $\begin{array}{l}18^{\circ} 42^{\prime} \mathrm{S} \\
39^{\circ} 51^{\prime} \mathrm{W}\end{array}$ & J. xanthus & Sweeping/1 male \\
\hline $\begin{array}{l}\text { Estação Biológica Santa Lúcia } \\
\text { (Santa Teresa, ES) }\end{array}$ & $\begin{array}{l}19^{\circ} 56^{\prime} 08^{\prime \prime} \mathrm{S} \\
40^{\circ} 36^{\prime} 01^{\prime \prime} \mathrm{W}\end{array}$ & J. marshi n.sp. & Sweeping/1 female, 4 males \\
\hline $\begin{array}{l}\text { Parque Estadual do Desengano } \\
\text { (Santa Maria Madalena, RJ) }\end{array}$ & $\begin{array}{l}21^{\circ} 50^{\prime} \mathrm{S} \\
41^{\circ} 40^{\prime} \mathrm{W}\end{array}$ & J. atlanticus n.sp. & Yellow pan traps/ 1 female; Sweeping/ 6 females, 4 males \\
\hline $\begin{array}{l}\text { Reserva Biológica do Tinguá } \\
\text { (Nova Iguaçu, RJ) }\end{array}$ & $\begin{array}{l}22^{\circ} 45^{\prime} 33^{\prime \prime} \mathrm{S} \\
43^{\circ} 27^{\prime} 04^{\prime \prime} \mathrm{W}\end{array}$ & J.atlanticus n.sp. & Yellow pan traps/1 male; Sweeping/3 males \\
\hline $\begin{array}{l}\text { Estação Ecológica de Juréia-Itatins } \\
\text { (Peruíbe, SP) }\end{array}$ & $\begin{array}{l}25^{\circ} 00^{\prime} 53 " \mathrm{~S} \\
47^{\circ} 55^{\prime} 36^{\prime \prime} \mathrm{W}\end{array}$ & J. atlanticus $\mathbf{n . s p . ~}$ & Sweeping/1 female, 2 males \\
\hline $\begin{array}{l}\text { Parque Estadual do Pau Oco } \\
\text { (Morretes, PR) }\end{array}$ & $\begin{array}{l}25^{\circ} 28^{\prime} 37^{\prime \prime} \mathrm{S} \\
48^{\circ} 59^{\prime} 28^{\prime \prime} \mathrm{W}\end{array}$ & J.marshi n.sp. & Sweeping/1 female \\
\hline $\begin{array}{l}\text { CEPA-Rugendas } \\
\text { (São Francisco do Sul, SC) }\end{array}$ & $\begin{array}{l}26^{\circ} 13^{\prime} 40^{\prime \prime} \mathrm{S} \\
48^{\circ} 40^{\prime} 49^{\prime \prime} \mathrm{W}\end{array}$ & J.atlanticus n.sp. & Sweeping/1 male \\
\hline
\end{tabular}



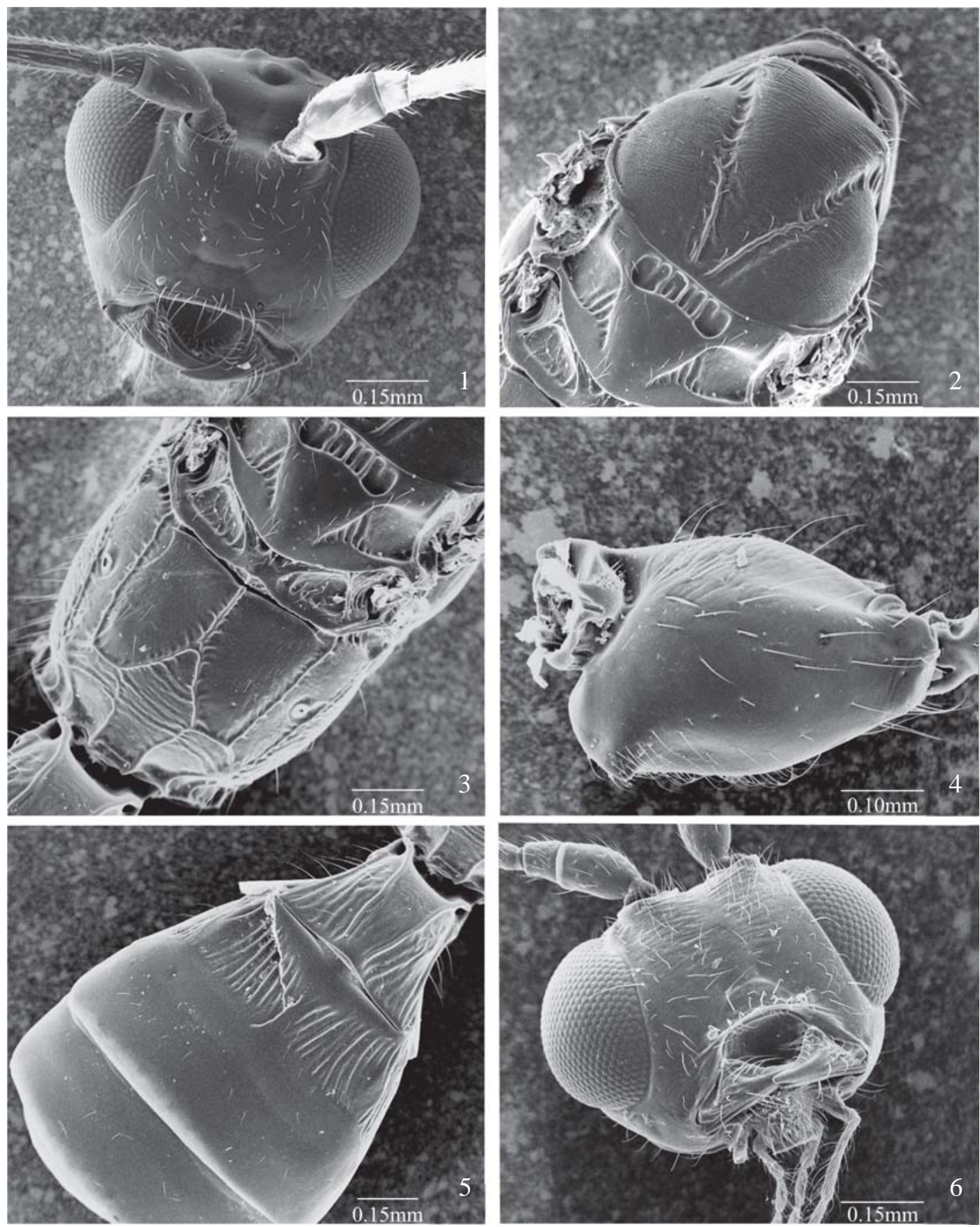

Figs. 1-5. Johnsonius marshi n. sp.: 1, head, frontal view; 2, mesonotum; 3, propodeum; 4, hind coxa; 5, metasoma, dorsal view. Fig. 6, Johnsonius atlanticus n. sp., head, frontal view.

\section{Johnsonius marshi n. sp}

(Figs. 1-5)

Holotype, female. Body length: 3.5-5.0 mm. Color: head honey yellow with vertex brown, antenna black; pronotum brown, propleuron yellow; mesonotum dark brown or black, honey yellow on notauli region and scutellar disk; mesopleuron mostly brown dorsally and dark brown or black ventrally; tegula and propodeum yellow; metasomal terga I-III yellow, IV-VI black dorsally and yellow laterally, remainder of terga and venter of metasoma yellow; legs yellow except apex of hind tibia and all tarsi brown; wings dusky, veins brown. Head: face smooth and shining, malar space 0.4 eye height, clypeus not margined by a distinct carina (Fig.1), frons smooth, vertex weakly striate, gena smooth, occipital carina meeting hypostomal carina; antennae broken, with at least 31 antennomeres. Mesosoma: pronotum smooth with median longitudinal carina; mesoscutal lobes coriaceous, notauli scrobiculate anteriorly and meeting scutellum with a pair of carinae (Fig. 2); scutellum smooth except for carinae; 

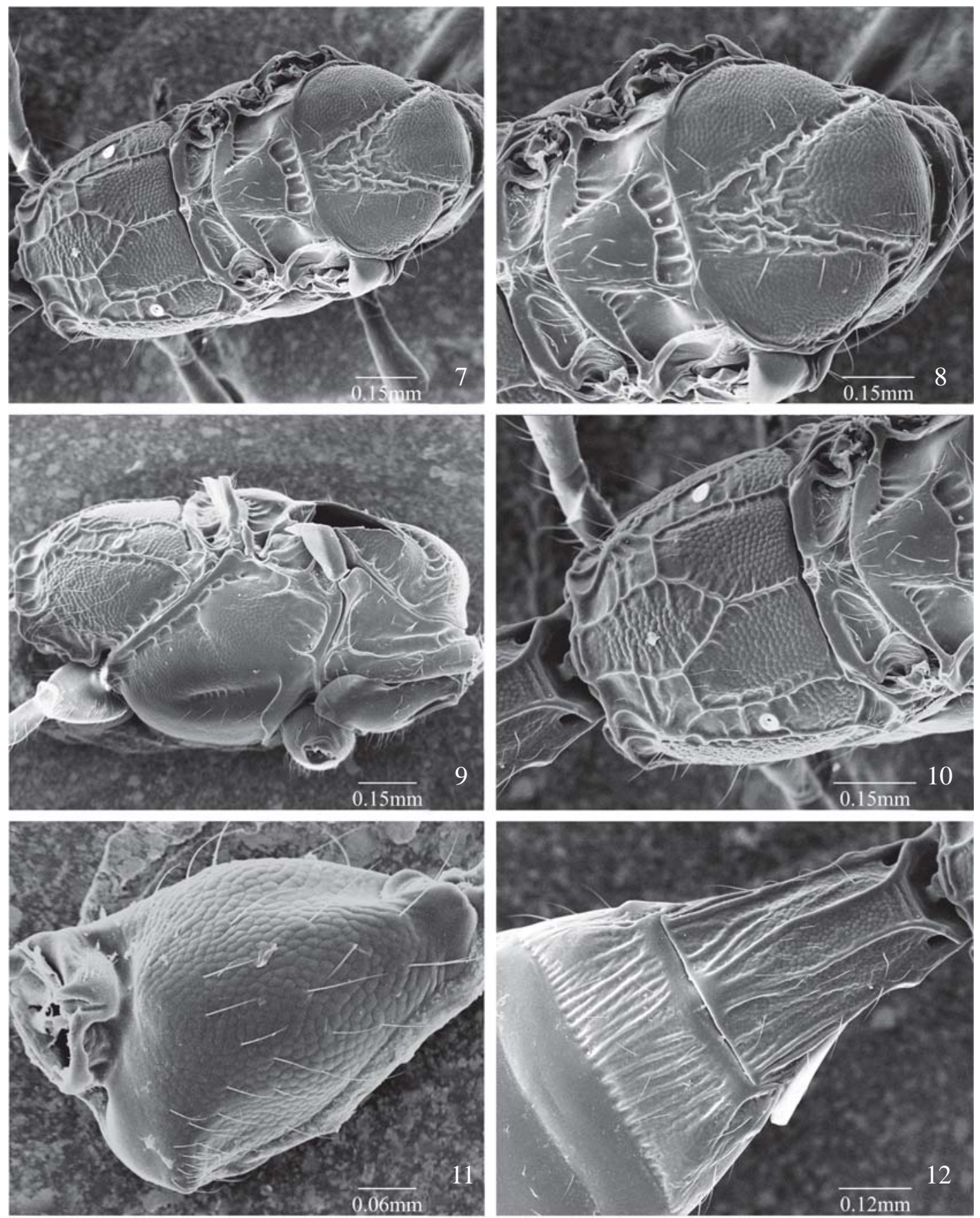

Figs. 7-12. Johnsonius atlanticus n. sp.: 7, mesosoma, dorsal view; 8, mesonotum; 9, mesosoma, lateral view; 10, propodeum; 11, hind coxa; 12, metasoma, dorsal view.

mesopleuron smooth, sternaulus deep and smooth; propodeum smooth or weakly acinose dorsal medially and striate-rugose apical laterally, distinct median and laterals carinae and areola (Fig. 3). Legs: hind coxa with basal tooth, finely striate-rugose dorsally, smooth laterally and basally (Fig. 4); fore and middle tibia with spines along anterior edge. Wings: fore wing vein $\mathrm{r} 0.5$ times length of vein $3 \mathrm{RSa}$; vein $\mathrm{r}$ $\mathrm{m}$ present, vein $\mathrm{m}-\mathrm{cu}$ distinctly basal to $2 \mathrm{RS}$, vein $1 \mathrm{cu}-\mathrm{a}$ distinctly apical to vein $1 \mathrm{M}$, first subdiscal cell open and often with dark spot on 2cu-a region; hind wing vein $\mathrm{M}+\mathrm{CU} 0.4$ of
$1 \mathrm{M}, \mathrm{m}$-cu curved at tip toward wing apex. Metasoma: first tergum equal to or slightly longer than apical width, longitudinally costate with a pair of carinae dorsally reaching apex of tergum; second tergum longitudinally costate, remainder of terga smooth and shinning (Fig. 5); ovipositor about equal to length of metasoma.

Male. Essentially as in female; antenna dark brown, pronotum light brown; third tergum dorsally dark brown and seventh tergum light brown.

Holotype. ㅇ (DCBU), BRAZIL, ES, Santa Teresa, Estação 


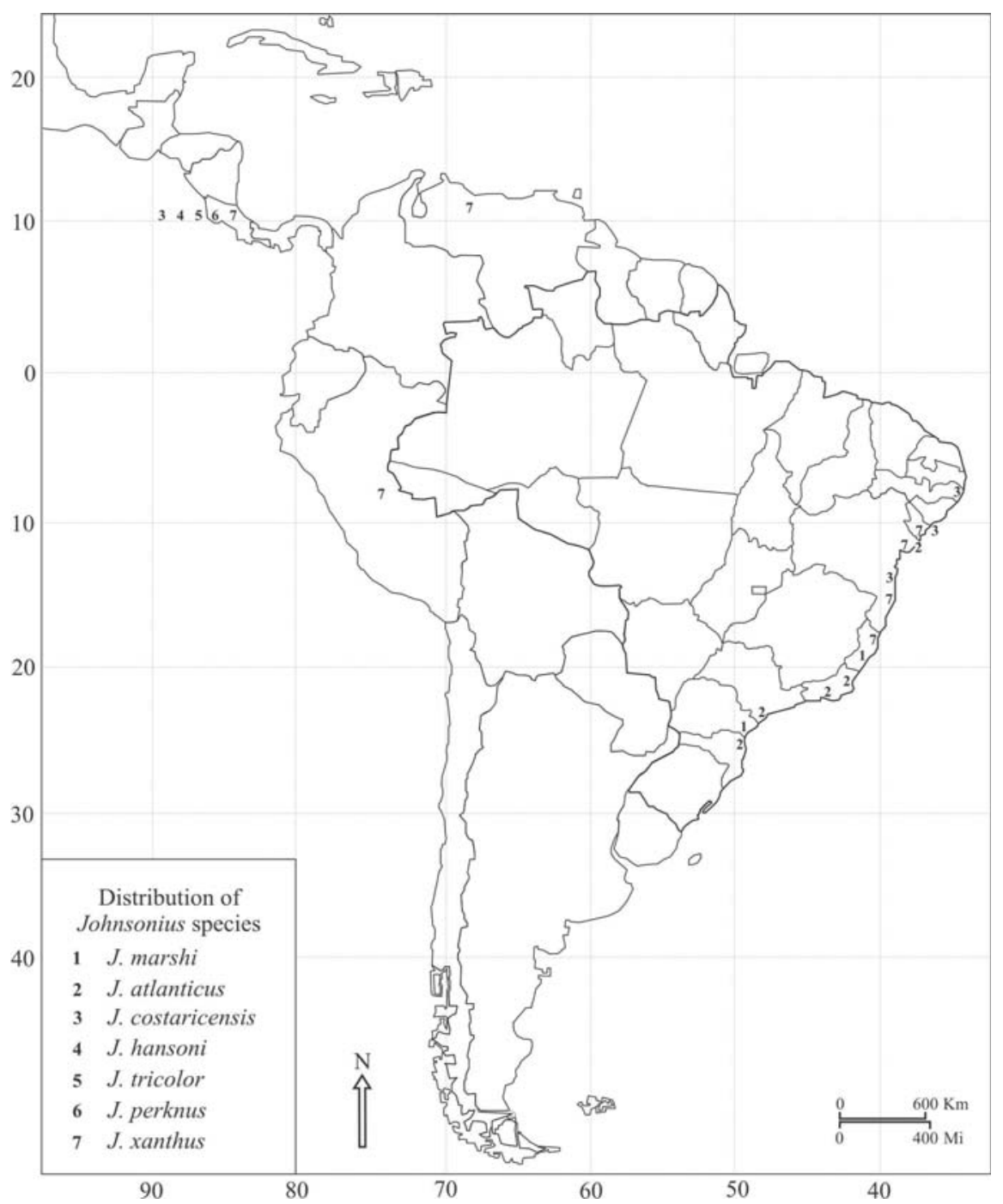

Fig. 13. Map indicating the distribution of Johnsonius species.

Biológica Santa Lúcia, sweeping, 7.iv.2001, C. O. Azevedo and team cols.

Paratypes. (DCBU, MZUSP), BRAZIL. ES, Santa Teresa, Estação Biológica Santa Lúcia: $3 \sigma^{x} 0^{x}$, sweeping of vegetation, 7.iv.2001, $1 \sigma^{x}$, sweeping of vegetation, 11.iv.2001 C. O. Azevedo and team cols. PR, Morretes, Parque Estadual do Pau Oco, 1 + , sweeping, 9.iv.2002, M. T. Tavares and team cols.

Etimology. The species was named in honour to Paul M. Marsh who has mostly works about the Doryctinae.

\section{Johnsonius atlanticus n. sp}

(Figs. 6-12)

Holotype, female. Body length: 2.5-5.0 mm. Color: head yellow, scape and pedicel honey yellow, flagellomeres dark brown; pronotum and propleuron yellow; median mesoscutal lobe and mostly scutellum brown, scutellar disk and lateral mesoscutal lobes honey yellow; mesopleuron and tegula yellow; propodeum yellow, except areola occasionally honey yellow; wings slightly dusky, veins honey yellow; first metasomal tergum brown at least apically, terga III-V brown dorsally, yellow laterally, remainder of terga yellowish; legs yellow, hind tibia and tarsi often brown, ovipositor yellow. Head: face finely striate-rugose, clypeus margined by inconspicuous carina (Fig. 6); frons and vertex weakly striate, gena smooth, occipital carina meeting hypostomal carina; malar space 0.35 eye height; 32 antennomeres. Mesosoma: (Fig. 7) pronotum smooth, occasionally weakly acinose and with longitudinal carina; mesoscutal lobes coriaceous, notauli scrobiculate meeting before scutellum in a large triangular rugose area (Fig. 8); scutellum smooth, scutellar disk weakly acinose; metanotum smooth; mesopleuron and propodeum coriaceous, sternaulus scrobiculate (Fig. 9); propodeum with distinct median and laterals carinae and areola (Fig. 10). Legs: hind coxa acinose and with basal tubercle (Fig. 11); fore and middle tibia with spines along anterior edge. Wings: fore wing vein $\mathrm{r} 0.5$ length of vein $3 \mathrm{RSa}$; vein $\mathrm{r}-\mathrm{m}$ present, vein $\mathrm{m}-\mathrm{cu}$ distinctly basal to $2 \mathrm{RS}$, vein 1cu-a distinctly apical to vein $1 \mathrm{M}$, first subdiscal cell open and often with dark spot on $2 \mathrm{cu}-$ 
a region; hind wing vein $\mathrm{M}+\mathrm{CU} 0.5$ of $1 \mathrm{M}, \mathrm{m}$-cu curved at tip toward wing apex. Metasoma: first tergum longer than apical width, longitudinally costate with a pair of carinae dorsally reaching apex of tergum, delimiting an acinose area; second tergum longitudinally costate, remainder of terga smooth and shining (Fig. 12); ovipositor about equal to length of metasoma.

Male. Essentially as in female; mesoscutum, scutellum and dorsal part of propodeum often dark brown, metasomal terga I-VII brown dorsally.

Holotype. क (DCBU), BRAZIL, RJ, Santa Maria Madalena, Parque Estadual do Desengano, sweeping, 20.iv.2002, Penteado-Dias and team cols.

Paratypes. (DCBU, MZUSP), BRAZIL. BA, Mata de São João, Reserva de Sapiranga, 1 +, sweeping, 21.vii.2001, M. T. Tavares and team cols. RJ, Santa Maria Madalena, Parque Estadual do Desengano: 1 ㅇ $30^{\pi} 0^{\pi}$, sweeping, 18.iv.2002; 2 우오, sweeping, 20.iv.2002; 2 우 우 $1 \sigma^{x}$, sweeping, 21.iv.2002; 1 우, yellow pan traps, 16-19.iv.2002, Penteado-Dias and team cols. RJ, Nova Iguaçu, Reserva Biológica do Tinguá: $3 \sigma^{x} o^{x}$, sweeping, 7.iii.2002; $1 \sigma^{\pi}$, Yellow pan traps, 9-12.iii.2002, S. T. Amarante and team cols. SP, Peruíbe, Estação Ecológica de Juréia-Itatins: 1 \% , sweeping, 30.iv.2002; $20^{\pi} 0^{x}$, sweeping, 5.v.2002, N. W. Perioto and team cols. SC, São Francisco do Sul, CEPA-Rugendas, 1 ơ , Sweeping, 17.x.2001, Penteado-Dias and team cols.

Etimology. The species name refers to Atlantic forest where the material was collected.

Acknowledgments. We are thankful to the Conselho Nacional de Desenvolvimento Científico e Tecnológico (CNPq), Programa de PósGraduação em Ecologia e Recursos Naturais da Universidade Federal de São Carlos (PPGERN/UFSCar), Fundação de Amparo à Pesquisa do
Estado de São Paulo (FAPESP) for the financial support, to Instituto de Química de São Carlos da Universidade de São Paulo (IQSC/USP) for the Scanning Eletronic Microscopy (SEM) on the material and Paul M. Marsh reviewer of the manuscripts.

\section{REFERENCES}

Macêdo, M. V. de \& R. T. Monteiro. 1989. Seed predation by a Braconidae wasp, Allorhogas sp. (Hymenoptera). Journal of the New York Entomological Society 97: 358-362.

Marsh, P. M. 1991. Description of a phytophagous Doryctinae braconid from Brazil (Hymenoptera: Braconidae). Journal of Hymenoptera Research 93: 92-95.

Marsh, P. M. 1993. Descriptions of new Western Hemisphere genera of the subfamily Doryctinae (Hymenoptera: Braconidae). Contributions of the American Entomological Institute 28: $1-58$.

Marsh, P. M. 1997. Subfamily Doryctinae: p. 206-233. In: Wharton, R. A., P. M. Marsh \& M. J. Sharkey (ed.). Manual of the New World Genera of the family Braconidae (Hymenoptera). Special Publication of the International Society of Hymenopterists 1: $1-439 \mathrm{p}$.

Marsh, P. M. 2002. The Doryctinae of Costa Rica (excluding the genus Heterospilus). Memoirs of the American Entomological Institute 70: 1-319.

Scatolini, D. \& A. M. Penteado-Dias. 2003. Análise faunística de Braconidae (Hymenoptera) em três áreas de mata nativa do Paraná, Brasil. Revista Brasileira de Entomologia 47: 187-195.

Wharton, R. A., Marsh, P. M. \& M. J. Sharkey. eds. 1997. Manual of the New World Genera of the family Braconidae (Hymenoptera). Special Publication of the International Society of Hymenopterists 1: 1-439.

Wharton, R. A. \& P. E. Hanson. 2005. Biology and evolution of braconid gall wasps, p. 495-505. In: A. Ramon, C. W. Schaefer \& T. M. Withers, (ed). Biology, Ecology and Evolution of Gallinducing Arthropods. Science Publishers, New Hampshire.

Received 25/01/2007; accepted 23/11/2007 